\title{
A NORMA SENSÍVEL À PROVA DA VIOLÊNCIA: O CORPO A CORPO EM DISPUTA SOB A ÓTICA FENOMENOLÓGICA EM PSICOLOGIA DO ESPORTE ${ }^{1}$
}

\author{
The Proof of Violence to Test the Sensible Norm: \\ Body to Body Into Dispute Under the Phenomenological Perspective on Sport Psychology \\ La Norma Sensible Confrontada Por la Violencia: \\ el Cuerpo a Cuerpo en Disputa Bajo la Ótica Fenomenológica em Psicología del Deporte
}

Cristiano Roque Antunes BarreiRa

\begin{abstract}
Resumo: Estas análises apreendem o esporte como um fenômeno eminentemente intersubjetivo, explorando condições fenomenológicas que pressionam a prática esportiva a seus limites e, em seu extremo, à ruptura do próprio fenômeno esportivo: dá-se a passagem à violência. Evidencia-se a estrutura das tensões intersubjetivas que tanto concorrem para a excelência esportiva como arriscam ocasionar a ruptura do que lhe é próprio. Todo esporte se constitui colocando em disputa um objeto a ser dominado, mediador estruturante da competição. Quando o empenho agressivo atravessa o objeto da disputa e alcança direta e intencionalmente o outro, configura-se o esfacelamento da fronteira do esporte, sua ruptura para a esfera da violência. O conceito, usual em Psicologia do Esporte, de agressão instrumental prova-se impróprio para designar os esportes de combate. A experiência empática de ambos os adversários e de um terceiro, o árbitro, serão decisivas para a interpretação sobre haver ou não tal ruptura. Emerge das análises o conceito de norma de sensibilidade. Mais do que iluminar interações pessoais que, em contexto esportivo ou não, desembocam em violência, o delineamento desse conceito assinala toda uma dimensão corporal estética que funda a experiência de interação intersubjetiva desde a esfera hilética, isto é, aquela da afetividade sensível.

Palavras-chave: Psicologia do esporte, Empatia, Violência, Fenomenologia, Normas sociais.
\end{abstract}

\begin{abstract}
These analyzes grasp sport as an eminently intersubjective phenomenon, exploring phenomenological conditions that force the sports practice to its limits and, at its extreme, to break the sports frontiers: it emerges violence. The structure of intersubjective tension can both, lead to sporting excellence and leads to break sports limits. Every Sport is constituted by the dispute of na object to be dominated, the structuring agent of the competition. In sports, when the aggressive actpasses through the object of the dispute and reaches directly and intentionally the other, it is given the disintegration of its limits into the sphere of violence. As a usual concept in sport psychology, instrumental aggression proves to be unfit to designate combat sports. The empathic experience of both opponents and a third, the referee, will be decisive for the interpretation of the occurence of a violent phenomena or no. From the analysis, emerges a new concept: sensible norm. More than illuminate personal interactions culminating in violence, in sports context or no, this concept points to a whole aesthetic bodily dimension where is founded the intersubjective interaction experience from hyletic sphere, that is, the sensible affectivity.
\end{abstract}

Keywords: Sport psychology, Empathy, Phenomenology, Violence, Societal norms.

Resumen: Estos análisis perciben el deporte como un fenómeno sumamente intersubjetivo, explorando las condiciones fenomenológicas que obligan a la práctica deportiva a sus límites y, en su extremo, para romper el propio fenómeno deportivo: se da paso a la violencia. La estructura de la tensión intersubjetiva conduce a la excelência deportiva pero tambien existe el riesgo de rotura de sus fronteras. Cada deporte ponie en juego un objeto a ser dominado, agente estructurante de la competencia. En los deportes, cuando la fuerza agresiva pasa por el objeto de la competencia y alcanza directa e intencionadamente la outra persona, sucede la desintegración de sus fronteras, su rotura en el ámbito de la violencia. La agresión instrumental,concepto habitual em psicologia del deporte, se demuestra como siendo frágil para designar a los deportes de combate. La empatía vivida de los dos oponentes y una tercera, el árbitro, van a determinar la interpretación de si hay o no hay tal ruptura. Emerge de las análisis el concepto de norma de sensibilidad. Más de iluminar las interacciones personales que culminan en la violencia, en deportes o non, este concepto equivale a toda una dimensión coporal estética que hace la fundación de la experiencia de interacción intersubjetiva desde la esfera hilética, es decir, la afectividad sensible.

Palavras-clave: Psicología del deporte, Empatía, Fenomenología, Violencia, Normas sociales.

Apoio: Processo nº 2012/22729-0, Fundação de Amparo à Pesquisa do Estado de São Paulo (FAPESP). 


\section{Introdução}

Quando se pensa em esporte e violência, é comum ter em mente situações de brigas deflagradas entre atletas, entre torcidas ou aquelas entradas desleais que fazem pouco das mais elementares normas de convívio estabelecidas.

Em esportes de contato, em que colisões e jogos de corpo são regulares, como futebol, basquete e handebol, desentendimentos e confrontos do tipo são comuns. Os esportes de combate, por sua própria natureza ambígua, são frequentemente percebidos como violentos. Juntos, esportes de contato e de combate ilustram com precisão o tipo de fenômeno que se quer examinar aqui. Nesse estudo, interessam pouco as situações em que um atleta é deliberadamente violento, se auto-justificando pela pretensão incontornável de vencer. Interessa aqui a compreensão de como, no corpo a corpo da disputa, o fenômeno esportivo percorre seus limiares, colocando-se naquela zona de ambiguidade que, usualmente, é assumida como violência socialmente aceitável. Ao extrapolar essa zona de ambigüidade, o fenômeno da violência propriamente dito comparece aqui como um acontecimento paradigmático que rompe um tipo de acordo tácito, sensível, implícito à interação entre sujeitos e, no interior de determinados limites, largamente passível de modulação. Trata-se de um tipo de acordo que, extrapolando o caso particular do esporte, será batizado norma sensível.

As análises ora realizadas apreendem o esporte como um fenômeno eminentemente intersubjetivo. Nessa perspectiva relacional, explora condições fenomenológicas que pressionam a prática esportiva a seus limites e, em seu extremo, à ruptura do próprio fenômeno esportivo. Trata-se, aí, da passagem à violência. É comum o esporte ser pensado como um laboratório no qual o controle de variações condicionais é dado pela estrutura social da instituição esportiva. Assim, analisar a passagem à violência na esfera competitiva do esporte pode jogar luzes sobre elementos psicológicos determinantes do fenômeno da violência também em contextos estranhos a este. Essa consideração inverte a lógica predominante, onde leituras conceituais da violência fora do esporte informam a interpretação no meio esportivo, conforme será abordado. De antemão, adianta-se uma consequência ética central desta fenomenologia que coloca em questão uma das mais frequentes críticas a certas modalidades esportivas: os esportes ditos violentos não o seriam assim, ao menos com referência às vivências essenciais de seus praticantes. É certo que esses esportistas não hesitariam, entretanto, em reconhecê-los como vigorosos e mesmo perigosos, eventualmente até lançando mão da violência em seu vocabulário. Por outro lado, elementos determinantes da percepção que os enxerga como violentos são colocados em evidência ${ }^{2}$. Além disso, uma compreensão mais sensível

\footnotetext{
2 Isso possibilitaria apreender as primeiras fontes perceptivas da virulência do debate entre detratores e defensores de modalidades, não sem alguma razão, ditas violentas.
}

dos comportamentos dos atletas em situações extremas de jogo também poderá emergir destas análises, informando conceitualmente tanto aspectos a serem considerados para ajuizá-las criticamente, como elementos potencialmente decisivos para os trabalhos interventivos em psicologia, seja ela ou não do esporte. Ao tematizar determinados fenômenos, a perspectiva fenomenológica em Psicologia visa compreendê-los, analisá-los e explicitá-los informando conceitos que têm o propósito de, ao iluminá-los, fornecer critérios de fundamentação e orientação para a área da Psicologia. Desse modo, na perspectiva fenomenológica de Edmund Husserl, o correlato de consciência de dado objeto investigado, quer reduzi-lo à sua condição de possibilidade pura, despido de tudo aquilo que o particulariza numa situação concreta. Já a Psicologia - uma vez que tenha esses recursos conceituais à mão - tem melhores condições para lidar e intervir junto a uma pessoa real e a uma comunidade com atenção à sua esfera psíquica. Assim, sem bastar-se nas questões esportiva e interventiva, assinala-se que o conceito que emerge das análises tem um potencial bem mais abrangente do que o tema em tela deixa suspeitar.

Quer-se examinar, então, como na intensificação do corpo a corpo em disputa, o fenômeno esportivo transita em seus limiares. Trata-se de um fenômeno complexo, cuja abordagem passa da orientação natural, situada no mundo em exemplos concretos, para efetivar um cercamento daqueles elementos vivenciais sem os quais o mesmo não aconteceria. A extração destas vivências determinantes é própria à orientação fenomenológica. Antes de se chegar à análise conclusiva e à sistematização final pelas quais se apresentam como essas vivências participam de um fenômeno cuja conceituação é aqui proposta nas trilhas dos pensamentos de Edmund Husserl (2006, 2007, 2014), Edith Stein (1922/1999) e Ales Bello (2004, 2006a, 2006b), o percurso a ser seguido cumprirá inicialmente três etapas: 1. Aproximação fenomenológica ao esporte apreendendo facetas de seu sentido genérico; 2. Faces da violência no esporte: fato e representação; 3. Violência e esporte: experiências liminares. Outras duas etapas, embasadas no percurso anterior do texto, discutem e concluem os aspectos sobre as normas sensíveis uma delineando-a e outra sistematizando seu conceito.

Deve-se logo advertir que há uma enorme distância em ver estas experiências e as condições de seus limites por dentro ou por fora. Desse modo, é pela conversão fenomenológica que se conduz certas objetividades a breves problematizações conceituais que querem, para pensar com Husserl, "tornar, assim, compreensível o equivalente de consciência do tipo de 'efetividade' em questão” (Husserl, 2006, p. 338). Assim, busca-se ver, em seu aspecto genérico, a estrutura das tensões intersubjetivas que, no acontecimento esportivo, tanto concorrem para sua excelência como arriscam ocasionar a ruptura daquilo que lhe é próprio no dilaceramento da violência. 


\section{Aproximação fenomenológica ao esporte: apreendendo facetas de seu sentido genérico}

Não é necessário aqui tentar cumprir uma inteira fenomenologia do esporte. Para o propósito de examinar o tipo de fenômeno que se pretende, pode-se permanecer tratando daquilo que será decisivo para a leitura de sua ruptura. Em filosofia, posicionado na orientação natural, já se afirmou que a regra se coloca como a fundação ontológica do esporte (Queval, 2009). Para um princípio de análise fenomenológica, contudo, a costumeira explicação contratual, que subjaz ao entendimento de como agem, se formam e do que estabelecem as regras, deverá ser convertida em apreensão experiencial. Aqui, passa-se da explicação regulamentar do esporte tomado como objeto, para o modo como os competidores se instalam numa relação intencional normatizada, ou seja, como o vivem em benefício do - e como condição sine qua non para o - andamento deliberado de uma disputa que os opõe na busca de um mesmo fim, vencer e não ser derrotado.

Subentendem-se aqui os rudimentos de uma fenomenologia da norma - tema cujo tratamento apropriado merece um estudo à parte. Dispersas em diferentes textos de Husserl $(2001,2011,2014)$, que vão dos inaugurais Prolegômenos à Lógica Pura (prontos em 1899) àqueles sobre a intersubjetividade (que se estendem de 1905 a 1935), entre outros, as ideias de norma contemplam toda a sua obra e uma fenomenologia da norma encontra níveis variados, sendo um dos mais elevados o da norma jurídica ${ }^{3}$. Para um entendimento inicial da constituição da norma, todavia, é preciso reconduzi-la a seu nível mais elementar, o da norma comunitária - e, antes, à própria evidência, como quer o fazer fenomenológico ${ }^{4}$. Ainda que também sejam tipos de norma, regras e regulamentos esportivos colocam-se como norma que delineia comunitariamente a tensão própria aos movimentos corporais que visam atingir os fins de uma modalidade esportiva. As normas comunitárias são as experiências que fundam as regras por proporem originariamente a direção da disputa, enquanto as regras configuram o registro acabado e pertencente à orientação natural. As regras, então, são edificadas a fim de garantirem a possibilidade das ações continuarem sendo agidas, especialmente por via de interdições. Estão interditas aquelas ações que afetariam gravemente a persistência da disputa. Dá-se o com-prometimento, expectativa comum de que o devir reserva, por parte dos envolvidos em situação determinada, ações dentro da

\footnotetext{
Embora não tão alto como o da norma ética (Husserl, 2001).

4 Um esboço de ideia de redução da norma a seu aspecto estritamente temporal - portanto transcendental - a apreende como expectativa de continuidade das coisas tal e qual já são ou estão sendo conhecidas. Este senso de permanência, que posteriormente pode ser representativo, categorizado ou regulamentado, anteriormente é ativo junto à consciência perceptiva como um devir normal, ou seja, como o horizonte de protensão que confirma, sem sobressalto, sem ruptura, mesmo em modificações dentro de certos limites, a continuidade de uma coisa enquanto aquela coisa.
}

normalidade. Descrito assim, esse registro normativo é aquele que posiciona seus sujeitos numa orientação personalista e que pode ser apreendido numa orientação fenomenológica ${ }^{5}$. Na prática, trata-se de existirem relações interpessoais imediatas, uma experiência comunitária equivalente à empatia atual ${ }^{6}$. Para seguir pensando com Husserl, deve-se mencionar também que essas relações "tomam emprestados caminhos indiretos" (Husserl, 2001, p. 283, nossa tradução), isto é, a instituição que foi instaurada historicamente pela vontade de outras pessoas (desconhecidas, inatuais) em relacionamento, portanto, produto de relações interpessoais passadas e sedimentadas como vontades reguladoras de práticas. Essas vontades sedimentadas não se fazem presentes tendo o sujeito atual como sua fonte originária, mas tendo-as sob seus olhos. Para o fenomenólogo, a própria comunidade humana é

(...) uma unidade que se constitui em média de normas e, de fato, normas cuja validade tem um caráter consciente, que limitam a ação dos homens, que circunscrevem as vontades do indivíduo particular de acordo com as esferas da livre vontade, opondo essas vontades à interdição. As normas valem, elas possuem uma validade sentida ${ }^{7}$. (Husserl, 2001, p. 214, tradução própria).

Institucionalizada ou não, uma comunidade é constituída por relacionamentos de pessoas que "formam a unidade de um contexto de ação espiritual" (Husserl, 2001, p. 283, nossa tradução). Não é excesso de cuidado lembrar que, na fenomenologia clássica, ação espiritual passa pela vontade e pelo sentido racional. No caso de uma modalidade esportiva, essa ação espiritual é encarnada e realizada em ações motoras, podendo, graças a isso, ser amplamente testemunhada e apreciada. Como se sabe, essa é uma condição essencial para que o esporte tenha uma esfera pública, sem o que ele não seria um fenômeno com tamanhas ressonâncias sociais e comerciais. Sua incorporação e aprendizado, em ação, equivalem a restrições e aberturas vivenciais volitivas e motoras que, ao mesmo tempo, se colocam como as vias possíveis da modalidade e dos sujeitos de sua prática no exercício da mesma. Em outras palavras, são as ações que podem ou não ser feitas pelo praticante naquela modalidade. Normas, assim apreendidas, não são regulamentos a serem pensados, triados

\footnotetext{
Portanto aqui, quando se falar de regra, deve-se ter em mente a orientação natural, a objetividade do que pode ou não pode ser feito. Quando se falar de norma deve-se ter em mente as direções possíveis e aceitáveis do sujeito em ação intersubjetivamente compartilhada. Ambas são correlativas e não excludentes num fenômeno como o esporte que não poderia se realizar na ausência de qualquer desses momentos.

${ }^{6} \mathrm{O}$ conceito de empatia tem uma precisão fenomenológica decisiva para o entendimento adequado destas reflexões. Não havendo espaço para sua retomada, recomenda-se a consulta a uma crescente produção bibliográfica que o tematiza nas perspectivas de Husserl e Stein (ALES BELLO, 2004, 2006a, 2014, 2015; Savian, 2014; Mahfoud e Massimi, 2013; Ranieri e Barreira, 2012;).

Validade sentida ou com ressonância, reconhecida.
} 
e avaliados pelo sujeito da experiência. Estas normas comunitárias correspondem a vias abertas na corporeidade - disposições, possibilidades à mão do sujeito, a que se recorre sem maiores mediações e tendo a vontade deliberada como seu gatilho. Os regulamentos, triagens, avaliações e pensamento, se colocarão a serviço dessas possibilidades de ação corporal - seja por quem as protagoniza, seja por quem as assiste ou arbitra visando garanti-las.

É aquele engendramento mútuo entre possibilidades da modalidade e dos sujeitos de sua prática que está na raiz da ação e da apreciação de um esporte, seja pelos sujeitos que o protagonizam, seja pelos que o assistem. Quem o protagoniza tem, na experiência de se conduzir no interior das normas, a constatação de ser capaz de agir suas possibilidades bem ou mal. Trazido para a esfera da experiência pessoal, está em jogo uma faceta decisiva do que é ser pessoa e que o fenômeno esportivo coloca em evidência: a ação e, com ela, o senso de realização, o senso de capacidade própria. Trata-se aqui, originariamente, não de uma evidência reflexiva, mas de uma evidência imediata, prática, que se dá à pessoa em carne e osso, tornando o esporte e as práticas corporais uma fonte de contato da pessoa consigo mesma cujos traços e alcance parecem apenas terem começado a ser examinados fenomenologicamente (a exemplo de Barreira, 2013; Valério, 2014). As possibilidades de um esporte são acionadas pelos atletas e há aqueles praticantes que, por fazerem-na com excelência, tornam o esporte um acontecimento admirável ${ }^{8}$. Aqui, é a apreciação do espectador que se revela no testemunho da ação atlética que faz bem feito aquele esporte, faz a modalidade liberar suas melhores possibilidades. Assim, não é a título de contrato que as regras de um esporte são apreciadas, mas a título de delineamento da ação esportiva, o que se reflete como acionamento da disputa no interior de suas normas.

Portanto, restrições e possibilidades de agir caminham juntas às normas. Mais do que apreciáveis, as melhores possibilidades do esporte, isto é, a excelência das ações dos atletas, fazem-no admirável. Já a inabilidade atlética, a incapacidade de liberar, no interior das normas, o fluxo da disputa por elas proposta também diminui a margem de apreciação do esporte, seja para protagonistas seja para espectadores. Dados esses passos, para se chegar à compreensão interna das tensões intersubjetivas que podem levar o acontecimento esportivo a seu máximo limite e à excelência, ou ao extremo e à sua ruptura, deve-se passar ainda pela extração do sentido daquilo que é o motivo da disputa esportiva: pelo que se disputa? Este motivo é o eixo em torno do qual toda vivência emerge e esmorece no esporte - pelo menos enquanto este não entra em colapso, como no caso das escaladas violentas.

Logo, uma vez que, na orientação natural já se acusara a regra como objeto fundador do esporte, uma vez que, passada à orientação fenomenológica, ela foi desnaturali-

Essa admiração foi descrita por Gumbrecht (2007) como fascínio. zada em seu equivalente de consciência, isto é, enquanto experiência comunitária corporal volitiva, cuja prática é normativamente instituída, pode-se passar precisamente à redução àquilo que ela normatiza. Não é demais advertir que, nessa redução, a espessura própria a cada uma das inúmeras modalidades esportivas dá lugar a uma generalidade vazia ${ }^{9}$. Para quem aprecia determinada modalidade em especial, essas passagens analíticas equivalem a uma perda de interesse, no sentido de que parecem tirar de cena o que é mais próprio a qualquer modalidade que se tenha em mente. Isso pode ser visto como mera abstração, quando, todavia, é o contrário. Não é uma abstração, mas uma penetração no fenômeno que permanece vivo e vibrante na intentio, a consciência de cada sujeito. Por isso, apreendendo as entranhas do esporte, cada leitor pode conferi-las imaginativamente começando pelo crivo de seu esporte mais apreciado e passando, um a um, por quaisquer outros. Trata-se de acompanhar imaginativamente a análise trazendo-a à vida. Ainda que vazia, trata-se de uma generalidade estrutural, evidenciando-se não apenas que sem regra não há esporte possível, mas que sem o quase esquecimento da regra, por via de sua incorporação expressa nas ações motoras normatizadas, o esporte não existe no mundo. Restaria aí sua suposição teórica, fictícia ou a tentativa prática de realizá-lo ${ }^{10}$. Em outras palavras, o motivo da norma tem que ser incorporado e acionado para existir e para se realizar uma modalidade esportiva. Então, ou esta evidência é falsa, e incorre-se em erro, ou qualquer esporte deve ser capaz de preencher intuitivamente o vazio inserindo-se com suas especificidades nesta estrutura intencional.

Todo esporte se constitui colocando em disputa um objeto a ser dominado, onde o domínio se define relativamente ao desempenho do adversário. Este objeto é o mediador estruturante da disputa e invocar a imaginação

\footnotetext{
9 Isso tem equivalências com o que é chamado por Isabelle Queval (2009) de "esquema simples", cujas consequências não serão exploradas aqui, embora seja válido frisar sua capacidade, como fenômeno raso, de absorver e reproduzir valores e ideologias.

${ }^{10}$ Esse seria o caso de alguma modalidade esportiva desaparecida que, apenas pela reconstituição de suas regras, se tentasse trazer à vida. O juego de pelota, prática pré-colonial da América Central que deixou inúmeras de suas quadras de pedra como resquícios arqueológicos de sua existência, é um exemplo bem registrado no Museo Nacional de Antropología na capital mexicana. Com tamanhos pouco inferiores ao das cestas de basquete, anéis de pedra nas laterais das quadras e posicionados verticalmente, deveriam ser atravessados por bolas feitas de borracha. Estas bolas deveriam ser lançadas com um golpe de quadril (em algumas versões com um golpe de cotovelo). A dificuldade para realizar a meta é imaginável e, com efeito, tentativas de fazer o jogo acontecer e interessar praticantes e espectadores não passam de simulacros que parecem não abrir as vias de ação que, ao longo de séculos, envolveram extensas zonas do continente atraindo multidóes. Inscrito nas regras, aquele legado não encontra mais sua inscrição nos corpos. Regulamentada, mas sem incorporação normativa, uma modalidade é apenas presumida, mas não posta em ação. Em outra direção, o esporte fictício imaginado por J. K. Rowling, praticado e celebrizado pelos personagens da série de livros e filmes protagonizados por Harry Potter, o quadribol, foi adaptado para a realidade e há alguns anos é objeto de competições federadas nos EUA.
} 
dá concretude à ideia exposta. Para as corridas - seja a pé, com obstáculos, na água (natação), em bicicleta etc. - o domínio de um percurso sobre o adversário equivale a um domínio temporal, significando, quase sempre, percorrê-lo no menor tempo ${ }^{11}$. Para os esportes de bola e similares, disco no hóquei, peteca no badminton, por exemplo - o domínio consiste em conduzi-la melhor que o adversário em direção à pontuação, seja o gol (futebol, handebol, rúgbi etc.), a cesta (basquetebol, juego de pelota), o buraco (golfe, sinuca), a área delineada no solo (vôlei, badminton), para lá do alcance do adversário (beisebol), a combinação de ambos (tênis, tênis de mesa, rúgbi novamente). Nos esportes de combate, em conformidade com as normas de cada modalidade, o domínio equivale a algum tipo de superioridade em restringir ou anular a mobilidade corporal do adversário ${ }^{12}$ (Barreira, 2013). Sempre, portanto, há um objeto constituindo e mediando a disputa esportiva.

\section{Faces da violência no esporte: fato e representação}

Nesse percurso fronteiriço, parecem entrar em cena duas possibilidades maiores. Por um lado, a excelência esportiva de uma ação extrema. Por outro, o colapso esportivo. Antes de se proceder a uma aproximação ao estreito limiar entre excelência e violência no esporte, é válido ter uma visão panorâmica do tema da violência no esporte, considerando a maneira como algumas de suas facetas comparecem como objeto da literatura.

Em artigo intitulado Sport and Violence publicado na International Review for the Sociology of Sport em 2004, Guilbert declara se juntar a "sociólogos que estudam formas flagrantes de violência, em vez de violência como tal, tentam abordar a violência nas áreas desportivas indiretamente, por meio de suas formas" (Guilbert, 2004, p. 47, nossa tradução). $\mathrm{O}$ argumento para isso é parcialmente compartilhado com um aspecto decisivo da filosofia fenomenológica: "violência objetiva não existe por si só” (Guilbert, 2004, p. 54). De fato, a fenomenologia tem compreensão similar, não apenas porque entende que toda objetividade é intersubjetivamente constituída, mas porque um fenômeno se define por ser algo inexoravelmente vinculado a uma consciência (Husserl, 2001, 2006, 2007). Todavia, a similaridade se interrompe aí. Afinal, as consequências do próximo passo argumentativo do autor levarão a um quase esvanecimento do objeto em questão: violência “é o produto de representações” (Guilbert, 2004, p. 54). O estudo assume que interessa saber como a vio-

\footnotetext{
${ }^{11}$ Existem também corridas de precisão, em que o domínio e a vitória são medidos pela proximidade com a chegada num tempo ideal previamente estabelecido, contando menos a velocidade do que a regularidade e logística.

12 Aqui, a rigor, deve-se falar em superioridade, pois mesmo numa condição de vantagem, o mero fato de que o oponente se empenhe em dominar a mobilidade do outro também restringe sua própria mobilidade.
}

lência é representada por atletas de modalidades tão diferentes como caratê, judô, natação, xadrez, futebol, basquete, tiro, tênis de mesa e tênis e leva aos atletas a pergunta sobre como representam as principais formas de violência em seus respectivos esportes. Daí, sucessivamente, decorre a lista de formas de violência, física, verbal, psicológica, trapaça e a enormidade de exemplos práticos destas formas: agarrões, brigas, agressões, golpes, quedas, abuso, ameaças, protestos, guerra de nervos, assédio, discriminação moral, corrupção, armações, uso de substâncias dopantes; estas são, diz o autor,"as mais frequentes formas de violência” (Guilbert, 2004, p. 46).

A vastidão de situações que estas formas e práticas ditas violentas abrangem não torna a compreensão do fenômeno - e sequer do objeto - mais fácil. Aí se confundem agressão com provocação, ação esportiva com ação antidesportiva, motivo com ato e indignação com vias de fato. No limite, a expressão "violência” perde o sentido do que possa designar. Pode-se ver aí o efeito da perspectiva representativa que, em ciências humanas e sociais, psicologia inclusa, herda de Dilthey (1833-1911) a reação ao positivismo naturalista. Como é bem sabido, a fenomenologia de Husserl, por sua vez, além de reagir ao determinismo naturalizador, responde também ao deslize psicologista. Contentando-se com um nível representativo, o psicologismo historicista escorrega e passa ao largo do alvo fenomenológico, deixa de penetrar o objeto e transita num terreno subjetivista, sem demarcação de critérios racionais últimos. O relativismo resultante explica porque, da representação que rejeita a existência de violência como objeto por si só, pode-se passar instantaneamente à naturalização que vê a violência como inerente a certas práticas esportivas. É o caso do juízo que o autor faz dos esportes de combate, ilustrado com o caratê e o judô. Aqui, a despeito de existirem representações que não os enxergam como violentos - o que, no Brasil, seria quase unanimidade, pelo menos quanto ao judô-, o autor assume como fato que "o propósito desses esportes é infligir violência ou lesão corporal sobre o adversário” (Guilbert, 2004, p. 49 e 50).

O tópico naturalista é, a partir daí, aquele que interessa examinar agora. $\mathrm{O}$ trabalho pontuado acima não é um exemplo isolado quanto ao juízo que faz dos esportes de combate e, com isso, do que seja a violência. Neste aspecto, o argumento do artigo está integralmente acompanhado por um dos mais célebres manuais de Psicologia do Esporte, o de Weinberg e Gould (2008). Pode-se considerar, ainda, que esteja parcialmente acompanhado pela posição oficial da ISSP, a International Society of Sport Psychology (Tenenbaum, Stewart, Singer \& Duda, 1997). Embora mais nuançado e conceitualmente diferenciado e cuidadoso, o artigo da ISSP silencia no que diz respeito aos esportes de combate. Dois dos conceitos referenciais usados no artigo, entretanto, são compartilhados por Guilbert (2004) e por Weinberg e Gould (2008), sendo que os últimos, inclusive, citam e se apoiam no texto da ISSP 
em sua argumentação. São eles os conceitos de agressão hostil e de agressão instrumental.

De maneira bastante objetiva o manual observa que "na agressão hostil, o principal objetivo é causar danos físicos ou psicológicos a outra pessoa, enquanto a instrumental ocorre na busca por um objetivo não-agressivo" (Weinberg \& Gould, 2008, p. 553). Na sequência, assim como Guilbert, para quem "o propósito desses esportes [de combate] é infligir violência ou lesão corporal sobre o adversário" (Guilbert, 2004, p. 49 e 50), os autores do manual afirmam que

(...) quando um boxeador acerta um golpe forte na cabeça de um adversário, há geralmente ferimento ou prejuízo. Entretanto, tal ação é um exemplo de agressão instrumental: o principal objetivo do boxeador é vencer o assalto e, causando danos a seu adversário (marcando pontos ou pondo-o a nocaute), pode conseguir seu intento (Weinberg \& Gould, 2008, p. 553).

É seguindo a mesma definição consagrada na Psicologia e usada no artigo da ISSP que Weinberg e Gould (2008) apontam os quatro critérios para definir violência: 1. É um comportamento (não uma atitude), 2. Envolve danos ou um ferimento, 3. É dirigida a um organismo vivo, 4. Envolve intenção. Um olhar com interesse fenomenológico, sem dúvida, se detém no significado do quarto critério, colocando a pergunta: Intenção de quê? A resposta é: intenção de ferir ou prejudicar. Os trabalhos citados julgam que esta intenção está no propósito dos esportes de combate. É nesse juízo que mora a visão naturalizadora da violência nos esportes de combate. Como se viu, embora a Psicologia do Esporte frise que a intenção é um dos quatro critérios da agressão (violência), a transposição desses conceitos oriundos da Psicologia em geral parece incorrer em limites importantes precisamente no quesito intencional. Tomada como vontade de ferir ou prejudicar, a intenção ou foi objetivada como natureza dos esportes de combate, racionalizada como instrumento visando fins calculados ou naturalizada como efeito de uma deliberação hostil. No primeiro caso, a objetivação vê a violência sempre presente nesses esportes. No segundo, ela é um efeito “maquiavélico". No terceiro caso, é a hostilidade que rege a deliberação voluntária do sujeito em sua ação. Se, por um lado, todas estas intenções podem comparecer nos esportes de combate, por outro, nenhuma delas apreende a especificidade intencional não violenta que os constitui.

\section{Violência e esporte: experiências liminares}

É aqui que conceitos usuais na Psicologia do Esporte, como agressão hostil e agressão instrumental, devem ser metodicamente suspendidos a fim de que o fenômeno "fale por si”. Nos esportes de contato físico, entre os quais os exemplos paradigmáticos são aqueles de combate, está regularmente previsto que certas formas e intensidades de contato corporal constituam a disputa. Designar indiscriminadamente esses comportamentos normativamente previstos de agressão com o sentido de violência, mesmo se envolvam danos físicos, como pode acontecer em certas lutas é, flagrantemente, ignorar o acordo intencional que envolve as partes da disputa. Ignorando-se este acordo intersubjetivo situado nas normas incorporadas, dá-se privilégio a um testemunho externo prendido à face física da ação. Deste aspecto sensacional, posto pela faceta física, decorre uma "empatia hermenêutica" - expressão usada por Husserl (2007) designando a apreensão do outro desde uma orientação interpretativa - que vê, onde quer que haja contato e dano físico potencial ou real, uma agressão deliberada, seja hostil ou instrumental, dirigida a outra pessoa.

Mas o que se perde com esta empatia hermenêutica, o que fica de fora desta apreensão interpretativa da ação intersubjetiva que está objetivamente refletida pelos conceitos usuais na Psicologia do Esporte? Perde-se precisamente a esfera intencional própria aos sujeitos da ação, substituindo-a pela interpretação intencional de quem testemunha. A distinção deve recuar ao objeto (o sentido, o fim) para o qual se direciona a ação do atleta. Como já foi assinalado, no combate, o objeto a ser dominado é o corpo do adversário ${ }^{13}$. No futebol, o objeto a ser dominado é a bola e a disputa incorre frequentemente em contato físico intenso. Assim, mesmo numa cena em que um atleta golpeia incessantemente a cabeça de outro, o fato de que esta ação consista num gesto efetuado para haver o domínio corporal do adversário, formalmente, subtrai qualquer violência do que é vivido pelos atletas. Fica em aberto, contudo, como cada pessoa vive, assistindo ou praticando, essa experiência. Esta percepção, em muitas circunstâncias, é atravessada efetivamente pelas vivências constitutivas da violência fazendo com que o combate esportivo acabe classificado como tal. Decerto, nos limites do âmbito esportivo, não há nada fisicamente mais parecido com a mais franca violência do que os combates.

$\mathrm{O}$ que torna o entendimento de que se deva subtrair da estrutura intencional do combate esportivo o sentido de violência uma exigência intelectual e ética, com efeito, é a deliberação voluntária dos lutadores de se colocarem numa disputa em que ser golpeado e golpear constitui a natureza da luta. Esta deliberação pode ser interrompida pelo próprio atleta durante o combate, ou pelo árbitro, quando entenda que o atleta não tem mais condições de se defender ou mesmo de sinalizar sua desistência. Se a exigência dessa redução for ignorada, ignora-se o que é ser vítima de violência, algo que escapa à vontade e à aceitação do sujeito, ao seu direito e à sua liberdade. Ignora-se também o que é ser sujeito da ação violenta, algo que de-

\footnotetext{
${ }^{13}$ Para um esclarecimento fenomenológico do combate, veja-se Barreira (2013). A especificidade do combate na forma de luta demonstra a centralidade do corpo próprio como objeto da disputa nas diferentes expressões culturais em esportes ou artes marciais.
} 
pende de uma intenção direcionada não ao corpo que se pretende dominar, mas à outra pessoa que, ao ser atacada, é anulada enquanto tal, isto é, anulada como pessoa ${ }^{14}$. Em qualquer esporte, é quando todo empenho agressivo atravessa o objeto da disputa, alcançando diretamente e, com certa intencionalidade, propriamente o outro com quem se disputa, que está configurado o esfacelamento de sua fronteira, sua ruptura para a esfera da violência. Nas belas palavras de Roland Barthes:

Produz-se uma espécie de provação do esporte pelo absurdo: é o escândalo esportivo. Esse escândalo se dá quando os homens rompem a tênue barreira que separa os dois combates: o do esporte e o da vida. Tendo perdido toda intermediação, privado de desafio e de regra, o combate dos jogadores deixa de ser submetido à distância sem a qual não há sociedade humana: volta a ser um conflito (Barthes, 2009, p. 104).

No atravessamento desta tênue fronteira, não é mais uma disputa esportiva, uma luta enquanto combate esportivo que está em cena, mas um conflito - um ataque à pessoa. Nessa ótica intencional, lutas não são conflitos, disputas esportivas não são violentas e, quando o forem, deixam de ser propriamente uma manifestação do esporte.

Entre os limites esportivos e seu rompimento, naquela tênue barreira, todavia, reside uma zona de ambigüidade na qual as possibilidades de excelência esportiva e de acontecimento violento ganham corpo chegando ao ponto de se consumarem ${ }^{15}$. Os conceitos de agressão hostil e instrumental designam fenômenos prontamente violentos. Um primeiro equívoco no uso de tais conceitos é a indiscriminação entre esporte e conflito. Um segundo equívoco é o de ler a agressão violenta como prontamente deliberada, como se todo comportamento agressivo que fere o oponente decorresse de uma decisão de ferir. Descarta-se da cena esta zona de ambiguidade, própria a tantos esportes de contato cujo processo obscurecido, talvez, possa ser iluminado com um aporte que considere mais de perto a corporeidade, isto é, a dimensão pré-reflexiva, afetivamente porosa e expressiva da materialidade vivida na ação. Este descarte acontece porque, sendo muito estreitos e focados no comportamento e em sua esfera cognitivo-emocional ${ }^{16}$ falham em apreender não apenas

\footnotetext{
14 Embora não se esteja fazendo referência direta, as considerações a respeito da violência aqui empreendidas são debitárias da fenomenologia cumprida por Hannah Arendt (1994), responsável por distinguir categoricamente violência de poder.

15 Também podem ganhar corpo aqui a falha, o erro do movimento em relação ao que se pretendia, assim como o acidente e a lesão. Essas possibilidades, todavia, se afastam da intenção de ir ao limite - fazer o melhor - e da ruptura que se quer examinar, a violenta.

${ }^{16}$ Esse enfoque na esfera psicológica acaba por apartá-la do mundo tal e qual se mostra e é vivido pelo sujeito de sua experiência. Dessa maneira, ao modo de uma teoria, a explicação de processos psicológicos pode ser aplicada sem maiores discriminações às mais variadas circunstâncias que guardam algumas similaridades. Parece ter sido o que aconteceu em certos aspectos de sua aplicação ao fenômeno esportivo.
}

as especificidades de dadas modalidades esportivas, mas as nuances experienciais pelas quais a situação violenta pode obscuramente vir à tona.

Abandonada a conceituação natural, pode-se reservar, a partir de agora, ao termo agressividade um sentido bastante originário. Agressividade se refere a uma excitação marcadamente intensificada que qualifica a orientação intencional de uma pessoa a um objeto ou mesmo a alguém ${ }^{17}$. Desse ponto de vista, não existiria ação esportiva sem alguma dosagem de agressividade. Em esportes em que há contato físico entre os atletas, porém, muitas das situações mais admiráveis têm elevada dosagem de agressividade ou, para dar-lhes um sentido narrativo, acontecem quando o mais provável seria exacerbar a agressividade, mas o que se testemunha é um balanceamento preciso da energia em favor da ação atlética. Pode-se pensar aqui no drible do jogador que, junto à marcação cerrada e dura de vários zagueiros, consegue concomitantemente tocar a bola, na medida para que ela não escape de seu alcance, e romper a barreira imposta pelos corpos dos adversários com força e leveza, para que o próprio corpo siga na jogada sem cometer uma falta de ataque, nem se deixar ser pego por uma penalidade. Ou num combate em que a trocação ${ }^{18}$ se intensifica tempestuosamente e, quando tudo parece empurrar um lutador ao descontrole e à incapacidade de se defender e resistir, uma ação tecnicamente precisa leva o seu adversário a nocaute ${ }^{19}$.

A questão que parece estar na raiz das dificuldades em se ler bem certos fenômenos mora no fato de que, nessas situações, a distância entre os contentores e o objeto mediador da modalidade, o objeto a ser dominado, parece ser apagada. Assim, a proximidade corporal no futebol, por exemplo, fará do drible que, por muito pouco, frustra o empenho agressivo alheio em acessar a bola, algo admirável, eventualmente uma bela expressão de excelência atlética. Ao mesmo tempo, para a vítima do drible, este pode ser sentido como provocativo e humilhante, motivo a mais para reagir interrompendo a continuidade da jogada com uma intervenção explosiva rumo à bola junto aos pés do adversário que o driblou. Aqui a zona de ambiguidade mostra sua confusão e relatividade, uma intencional, outra posicional.

\footnotetext{
${ }^{17}$ O dicionário histórico da língua francesa, Le Robert, aponta os usos iniciais do verbo agresser entre os séculos XIV e XVI com o sentido de provocar e excitar, estando relacionado a progredir e oprimir. Já seu vínculo com agressão data do século XIX. Agressão veio do latim agressio sendo usado inicialmente no século XIV associado a aggredi (atacar) e este vindo de gradus (passo, caminhar, progressão). Com sentido psicológico de instinto de agressão, o mesmo remete ao século XX por influência alemã e inglesa.

${ }^{18}$ A trocação designa o momento em que, de lado a lado, os adversários se golpeiam mutuamente, havendo pouco ou nenhuma diferença entre posições ofensivas e defensivas.

${ }_{19}$ Dois atletas, entre incontáveis outros, ilustram isso de modo célebre: Lionel Messi no futebol contemporâneo e Muhamad Ali no boxe dos anos 1960 e 1970, lutador que se deixava bater nas cordas, baixando a guarda e reagindo, muitas vezes nocauteando o oponente, num rápido, desconcertante e decisivo contra ataque.
} 
A confusão intencional significa mistura de vividos: determinação atlética (raça) e agressividade intensificada na ofensa; ofensividade como "dever" de dar o troco e recuperar-se após a desvantagem. Trata-se de explodir na bola ou nas pernas do driblador? Trata-se de ambos? Como saber bem, no frigir das ações, o que queria o jogador? Como saber se o que fez era o que queria fazer? Já a relatividade posicional está na perspectiva de cada envolvido, do jogador agressor, do jogador agredido e de um terceiro. Com efeito, há um terceiro e, eventualmente, mais de um, para os quais o desdobramento regulamentar da partida está junto ao árbitro. Sua interpretação do que se passa demarcará se é apenas um jogo de corpo, uma falta ou uma falta extrema, que exige que o jogador seja expulso da partida. Entretanto, outros terceiros intervêm. Um jogador do time de quem foi agredido pode, por exemplo, ver ofensividade excessiva e reagir bruscamente, acusando, desencadeando e amplificando um desentendimento e até uma briga. O próprio jogador agredido pode entender que a agressão é inaceitável e contra-atacar. Fora da zona de ambiguidade, o agressor, por sua vez, pode posicionar-se frisando que o fez deliberadamente e a vítima de sua entrada não teve mais do que o merecido. Diferentes interpretações, portanto, podem ser referentes ao posicionamento dos envolvidos, sendo relativas a seus pontos de vista.

Um dos episódios mais infames na história recente do boxe, e que ilustra bem essa saída da zona de ambiguidade com um ataque violento deliberado, ocorreu em 1997, na segunda luta entre Evander Holyfield e Mike Tyson. Em sua autobiografia, Tyson conta que, após a derrota na primeira luta no ano anterior, desnorteado a ponto de ter perguntado "a um dos caras da equipe em que assalto nocauteei Holyfield” (Tyson e Sloman, 2014, p. 285), ouviu seu treinador Crocodilo, dizer enfurecido: 'Olhe a sua cabeça, Mike!' [...] Eu tinha seis galos do tamanho de um punho, decorrentes das cabeçadas de Holyfield. Mais que isso, Croc estava convencido de que Holyfield estava usando esteróides” (idem). Tyson não inocenta sua equipe de já ter tido práticas como a de pagar os árbitros para favorecê-lo. Mas quanto a esta luta, acusa o árbitro de favorecimento ao adversário, por permiti-lo dar os golpes ilegais com a cabeça. Na luta seguinte, o árbitro seria outro, mas, a seu ver, não o desfavoreceria menos. Essas são algumas informações determinantes para ser lida a passagem que foi da zona de ambiguidade à sua ruptura na segunda luta, pelo menos de acordo com a versão de Tyson. Vê-se como a fronteira posta pelas regras pode ser manipulada escusamente, com o uso de substâncias dopantes, golpes ilegais, vista grossa de uma arbitragem tendenciosa em favor de um atleta, seja por corrupção ou mera preferência. À parte estas conjecturas trazidas pelo lutador, no momento da luta, as cabeçadas poderiam ser acontecimentos desenrolados no limite da regra, do corpo a corpo do combate, situando-se ambiguamente para lutadores, arbitragem e espectadores. Porém, o que poderia contar com a desculpa de ser acidental na primeira luta, seria visto por Tyson necessariamente como estratégia do oponente na segunda. Após receber algumas cabeçadas no novo confronto, o boxeador narra:

Eu queria matá-lo. Qualquer espectador podia ver que aquelas cabeçadas eram intencionais. Eu estava furioso e, como era um soldado indisciplinado, perdi a compostura. Eu mordi sua orelha. [...]

Daí em diante, não me lembro de muita coisa porque estava com muita raiva. Quando dei uma olhada na gravação, notei que devo ter cuspido o pedaço do lóbulo de sua orelha na lona, porque eu ficava apontando para lá. Era como se eu dissesse: 'É isso aí, você mereceu'. Eles de fato acharam o pedaço da orelha depois da luta e tentaram suturá-lo de volta, mas não deu certo. Holyfield deu um pulo no ar, cheio de dor, e se virou para voltar a seu corner, mas o segui e o puxei por trás. Queria chutá-lo na virilha, mas só o puxei. Eu me tornei um lutador de rua naquele momento. O médico deu uma olhada em Holyfield e permitiu que ele continuasse a lutar, e então Mills Lane me tirou dois pontos, mas nada disso me importava. Eles estavam todos contra mim de qualquer forma. Então, a luta continuou, e ele voltou com suas cabeçadas. E o árbitro, é claro, não fez nada. Entramos no corpo a corpo, e o mordi de novo na outra orelha, mas continuamos lutando até o final do assalto (idem, p. 288).

Embora o lutador se envergonhe do que se passou, se justifica e se defende:

Estavam dizendo que eu achava que apanharia, por isso comecei a morder. Isso é ridículo. Se fosse o caso, eu teria feito isso na primeira luta. Em todas as lutas que perdi, as pessoas me viram apanhar como um homem, nunca me esquivei. Ninguém tinha o direito de me chamar de cachorro. Eu estava irritado, com raiva, perdi a compostura. Eu mordi a orelha de Evander Holyfield porque estava enfurecido na hora e já não me importava mais em lutar segundo as regras do Marquês de Queensberry (idem, p. 290 e 291).

Considerar essa longa citação do episódio faz ver como a zona de ambiguidade não é atravessada apenas pela fisicalidade ou sensibilidade à dor e à pressão, mas, razoável ou não, por um sentimento de estar sendo injustiçado naquilo que se passa. Para o lutador, não há nada de inaceitável em apanhar dentro das regras - sua fúria provém do sentimento de injustiça que lhe toma. Há, aqui, um atravessamento mútuo que passa pelas regras, mas se encarna como uma norma sensível. Nem apenas regra, nem apenas sensibilidade, mas o entrelaçamento de ambas como vivido normativo, aquilo que informa o que se pode, o que não se pode, o que é aceitável ou não, em ação e, decisivamente, numa esfera pessoal-comunitá- 
ria. A pergunta que precisará ser respondida adiante é: se não é na sensibilidade e nem na regra propriamente dita, em que momento foram irrompidos os limites da norma sensível na experiência de Tyson?

De volta ao território liminar da ambiguidade, ao contrário de acusar como o oponente mereceu a agressão, como fez Tyson, sobressaem-se outras possibilidades de desdobramento. Como a de lamentar-se e desculpar-se por ter ocasionado um efeito indesejado, não pretendido. E a desculpa pode ou não ser aceita. Embora muitas sejam as possibilidades, em todas elas é a esfera do intercâmbio intencional e a esfera das consequências físicas que estará em jogo. Mas não separadamente. Uma falta não intencional pode provocar aguda indignação e ser considerada inaceitável por colocar a integridade física do adversário em risco, por exemplo. E uma falta levíssima pode ser da maior ofensa pelo teor intencional malicioso. Uma falta intencional pode ser tolerada por ser percebida como troco devido ou necessário, revide à altura de um jogo de corpo ou entrada mais dura sucedida anteriormente. Embora, à época, poucos tenham achado tolerável a mordida de Tyson, seu relato indica como, percebendo todos contra si, morder foi um revide aos golpes ilegais que frustravam seu desempenho e que estaria recebendo sob conivência da arbitragem. A torcida, como terceiro, também pode jogar um papel aqui, amplificando desafetos, reagindo a ponto de influir sobre o juízo do árbitro. E, não se pode deixar de mencionar, em meio a tudo isso se coloca o largo espaço para atuações quase cênicas e tentativas de tirar proveito da interpretação da arbitragem em favor próprio.

Em todo caso, há uma chance íntima de que determinadas situações limite tanto suscitem acontecimentos no registro da excelência esportiva quando rupturas esportivas vividas e vistas como violentas. Intencionalmente ou não, é o limite da situação esportiva que pede um empenho do sujeito no seu próprio limite, portanto à beira da desmesura. Trata-se de constatar aqui como a excelência esportiva está numa ação muito próxima a exceder limites, tanto do esporte como do atleta. A violência não é o único fenômeno que pode exceder tais limites, mas também as lesões, os pequenos e grandes colapsos psicológicos, os acidentes. Forçar o limite como concepção de superação de si, ultrapassagem do que possa haver de natural na existência (Queval, 2013), vai de par com padrões de medicalização que, quando não apenas flertam com, consumam outro excesso, responsável por empurrar a linha dos limites próprios para mais longe, o doping (Sandel, 2013). Naquela zona de ambiguidade, o fenômeno dito violento parece sempre, aos olhos de quem o classifica assim, um fenômeno de desmesura intercorporal pelo qual há um empenho agressivo tão intenso para a realização da tarefa esportiva que este borra a existência do outro, ocasionando o risco ou perigo de lhe ferir, isto é, sua probabilidade ou efetivação com consequências físicas mais ou menos graves, mais ou menos permanentes. Ser borrado significa, efetivamente, não ser mais visto pelo outro ou perceber-se como não sendo mais visto. Pode ainda ser externamente classificado como violento, seja por parte do árbitro, seja por parte dos espectadores. Como foi visto anteriormente, essa classificação externa foi conceitualmente aplicada ao boxe, tendo suas ações apontadas como exemplo de violência instrumental - definida aqui pelas ações de bater e apanhar com prejuízo a alguém. Mike Tyson, todavia, não se indignava por apanhar, mas por se sentir borrado, por se ver vítima de algo inaceitável; tendo "todos contra” si, enfureceu-se e reagiu violentamente. Responde-se à pergunta feita dois parágrafos acima: é nesse momento que se irrompem os limites da norma sensível na experiência do boxeador. Na zona de ambiguidade, é quando o corpo a corpo emerge como indignação crescente, a partir de um proto-sentimento de injustiça, que pressão física, dor e frustração motora prescrevem vias objetivas à violência. No geral, a pluralização gradual de pontos de vista recíprocos da situação que ocasiona este proto-sentimento o amplia, tornando-o um sentimento propriamente dito, em que há sua vítima, seu algoz e seu testemunho. São as posições adotadas nessa ampliação que tornarão possível a passagem do sentimento aos juízos de justiça.

Coloca-se aqui a questão da percepção da zona de ambiguidade como problema de ordem cultural na legitimação de modalidades esportivas de combate, cujo exemplo mais vivo atualmente é o MMA (Mixed Martial Arts). Quando o fenômeno se passa entre os envolvidos, não ser mais visto, ou perceber-se assim, consiste na entrada na zona do conflito, no deslize para fora do espaço de disputa, o escândalo esportivo. É como atleta que a pessoa que é borrada deixa de ser vista. Não é mais alguém numa disputa esportiva, mas alguém num conflito violento. E alguém num conflito violento é alguém sujeito a um processo de coisificação (Barreira, 2013). Ser visto, por sua vez, é ser tratado e ser assim percebido, na prática do corpo a corpo, com o respeito previsto pelas margens da ação normatizada. São inúmeras aqui as possibilidades pelas quais, inflada ao extremo, de parte a parte, e sem necessária deliberação cognitiva, a zona de ambiguidade se enche de desafeto, se agudiza duramente em reação corporal percebida como efetivamente hostil, desencadeando uma escalada que se consuma em violência propriamente dita.

\section{O corpo a corpo: engendramento de normas de sensibilidade}

Em vias dos argumentos conclusivos, é o momento de lembrar um dos motes disparadores das reflexões e análises aqui empreendidas. Fala-se muito em violência no esporte e em esporte violento. Isso é legitimado na concepção de processo civilizatório aplicada ao esporte por alguns de seus principais teóricos, Norbert Elias e Eric Dunning (1994). Na esteira desse pensamento segue toda 
uma linha em sociologia do esporte. Assim, haveria uma gradual redução dos graus ou parâmetros de violência aceitável no esporte paralela ao progresso civilizatório. O percurso aqui empreendido põe em questão se há, de fato, no esporte, graus aceitáveis de violência. Da perspectiva fenomenológica, todo o problema desta discussão está na naturalização ou psicologização com a qual o fenômeno violência é apresentado. Naquele, trata-se de determiná-la pela faceta física das ações; nesta, trata-se de relativizá-la com base em convenções socialmente definidas. Ambas - naturalização e psicologização - são insuficientes para compreender o fenômeno exatamente em virtude de se prenderem respectivamente aos polos físico e psicológico do mesmo.

Uma vez que a crítica a este tratamento da violência já foi cumprida, incidindo lá onde a problemática se inaugura, pode-se penetrar na constituição do complexo intencional que atua obscuramente no uso deste juízo objetivado de violência. Assim, se a ideia de parâmetros aceitáveis de violência no esporte é suspendida, todavia, pode-se afirmar, sem maiores análises, que há parâmetros aceitáveis de direcionamento da agressividade no corpo a corpo entre os sujeitos envolvidos na disputa. Nesse caso, é a percepção de ruptura de parâmetros de agressividade aceitável que é avaliada como efetivação do fenômeno violência. A partir desse argumento, defende-se que o conceito de violência deva designar o inaceitável no esporte. A violência não se dá apenas por intensificação agressiva, não se dá apenas pela ultrapassagem de um grau x de agressividade, mas sim no momento em que, seja qual for o parâmetro de agressividade usado, haja o desbotamento do outro numa ação que o coisifica agressivamente. Paradoxalmente, é isso que torna tão razoável para os detratores de modalidades esportivas de combate classificá-las como violentas. E isso porque, em sua percepção, há violência porque eles vêem e sentem naquelas ações físicas o apagamento do outro.

Não é mais suficiente considerar a confusão intencional e a relatividade posicional - primeira pessoa (agressor), segunda (agredido) e terceira pessoa (testemunha, arbitragem) - para apreender toda a complexidade ativa nos parâmetros em pauta. Embora ambas sejam as condições vivenciais profundamente estruturantes do fenômeno e de suas variações, também é preciso considerá-las superficialmente. A superficialidade aqui equivale a ver o fenômeno ingenuamente, sob a orientação natural, evidenciada em suas primeiras aparições e nas consequentes comparações cognitivas de suas variações. Há um paralelo irrevogável entre aparição superficial e fenômeno, aquela sendo dada como fato percebido sob orientação natural, este sendo apreendido fenomenologicamente e revelando a profunda estrutura do que está à superfície. Provisoriedade e precariedade, evidenciadas na atitude natural, estão fundadas respectivamente na relatividade posicional e confusão intencional. É sob a rubrica de um parâmetro estável, a regra, por excelência, que as frontei- ras entre disputa e conflito no corpo a corpo anunciam suas provisoriedade e precariedade. É ainda pré-reflexivamente que fenômeno fronteiriço e parâmetro estável (regra) contrastam possibilitando sua comparação e avaliação. Em uma luta esportiva de caratê um golpe pode ser percebido por quem o recebe como rompendo os limites do semi-contato, havendo aí uma expectativa de que seja marcada a infração. O oponente que golpeou, por sua vez, pode perceber a intensidade do impacto de seu golpe como bem controlada e adequada à regra. Nos parâmetros da regra, caberá à arbitragem tomar uma decisão que, naquele momento, normatiza a modulação da intensidade aceitável. No futebol, a atribuição de cartão amarelo e vermelho deixa à arbitragem a função de modular a intensidade das ações toleráveis e intoleráveis, recaindo frequentemente em controvérsias. Como se constata, embora decisiva, não é claramente na regra que habita o delineamento do parâmetro de agressividade aceitável na disputa corpo a corpo. A passagem entre disputa e conflito situa uma zona corporal de ambiguidade. É aí, no corpo a corpo, que se pode encontrar a constituição do que merece o apelido de normas sensíveis, isto é, de uma esfera comunitária sensível ${ }^{20}$. Embora, até onde se pudesse averiguar, a expressão norma sensível ou norma de sensibilidade não apareça no trabalho de Husserl, seus escritos lançam as bases para que o conceito seja cunhado. O fenomenólogo frisa a constituição de um mundo sensível comum, a abertura para o mundo ambiente que é compartilhada pela pluralidade de sujeitos em comunicação ${ }^{21}$. Assim, escreve que

Cada indivíduo possui sua sensibilidade, suas apercepções e suas unidades duráveis: a pluralidade em comunicação possui, sem dúvida, igualmente, de certa maneira, uma sensibilidade, uma apercepção durável e, a título de correlato, um mundo dotado de horizonte de indeterminação. Eu vejo, eu ouço, eu não tenho experiências somente com os meus sentidos, mas também com aqueles dos outros. (Husserl, 2001, p. 290, nossa tradução).

Coloca-se assim, já naquelas análises, a base de um mundo comum e de uma sensibilidade comum correlata a esse mundo. Como já se viu, sob a ideia de norma coloca-se também em cena uma comunidade espiritual, certa unidade de sentido. Como a corporeidade participa na constituição dessas normas de sensibilidade? Aqui, aquilo que Husserl denomina base hilética, pré-reflexiva, abrangendo atos que vão da reatividade impulsiva, à dor, pressão e força sensíveis impostas e sofridas, fornece os

\footnotetext{
${ }^{20}$ Se também podem ser chamadas normas intercorporais, deve-se lembrar que não há normas sem intersubjetividade e, se a intersubjetividade está implícita na ideia de norma, é o adjetivo sensível aquele que melhor contempla a especificidade dessas normas.

${ }^{21}$ Trata-se do §.4 de texto intitulado "Espírito comum II: Unidades Pessoais de classe superior e seus correlatos de ação”, escrito em 1918 ou 1921 (Husserl, 2001).
} 
índices de validade e limites das ações intercorporais aceitáveis e inaceitáveis, toleráveis e intoleráveis. Seriam quantificáveis tais limites? Há pouco espaço - e se houvesse mais, isso implicaria um contorno muito amplo - para detalhar como na resposta negativa a esta pergunta reside uma verdadeira encruzilhada para alguns dos principais problemas epistemológicos da Psicologia. No entanto, não se pode deixar de mencionar que Edith Stein (1999) enfrentou esses problemas tematizando de maneira muito promissora e ainda pouco explorada a questão da causalidade psíquica (ALES BELLO, 2015). De certo modo, Stein identifica e mapeia a encruzilhada. A fenomenóloga mostra que as relações entre dados sensoriais, ou dados físicos e percepção não podem ser reduzidas a fatores quantificáveis. A relação de causalidade que existe entre ambos é sempre mediada por aquilo que ela denomina estado vital e sentimento (ou energia) vital. Sua determinação não pode ser quantitativa, mas apenas qualitativa, nem por isso deixando de haver conexões necessárias e leis adequadas para a esfera psíquica. Nesse sentido, aqueles índices para as ações intercorporais aceitáveis e inaceitáveis nem são definitivamente quantificáveis, nem são generalizáveis entre os indivíduos ${ }^{22}$. Isso não exclui que, com base no reconhecimento de leis de causalidade psíquica, tendências e probabilidades possam ser previstas com alguma segurança. É na experiência vivida que residem essas possibilidades de ordem primariamente qualitativa (aqui, quantificações são apenas aproximações empíricas e inexatas). Essas experiências não encontram, naturalmente, outro lugar para serem vividas que não o corpo. Nem encontram outro lugar para se manifestarem e sistematizarem que não, respectivamente, nas relações interpessoais e na cultura.

No caso do esporte, de experiência em experiência, a repetição e o treinamento são determinantes para que estas ações encontrem seus diferentes tipos de limites intercorporais. Lembrando que, como se tratam de esportes de contato, não poderia ser diferente, mas precisamente pelo senso tátil que a delimitação material do corpo próprio, bem como sua resistência sensível e empenho motor, constituem o estrato intencional primário que se faz acompanhar de atos avaliativos e volitivos capazes de posicionar pessoalmente o sujeito da experiência atlética. Mas isso merece um pequeno exame, pois pode sugerir que uma vontade forte seja suficiente para evitar a intolerância e resistir à pressão.

Nas ações decisivas inseridas no contexto esportivo de contato físico existe efetivamente pouco tempo e espaço para a proeminência de atos intelectivos de tipo representativo e reflexivo com maiores elaborações. O tipo

\footnotetext{
${ }^{22}$ Por definitivamente, entenda-se quantificáveis de uma vez por todas, como pode ser o peso de um dado objeto e certas relações causais da esfera material da realidade. Pensado como medida física, qual o peso do intolerável? Esta é uma resposta que não pode ser dada. Qualitativamente, porém, o peso do intolerável, a partir de dada circunstância, pode ser identificado e descrito, inclusive naquilo que possa ter de generalizável, isto é, em suas tipificações.
}

de exigência da ação esportiva torna a proeminência reflexiva contraprodutiva, um empecilho à imediaticidade entre vontade e movimento, decisão e ação, gesto pré-reflexivo, mas volitivo, que prova a motricidade corporal como o mais direto e puro instrumento da vontade. Em suas análises, Husserl mostra como o corpo vivo é "órgão da vontade, o único objeto que a vontade do meu eu puro pode mover livremente e espontaneamente" (Husserl, 2011, p. 154, nossa tradução). Mediações intelectivo-representativas eficazes para a vontade do atleta tendem a ser nada mais do que antecipações encarnadas das possibilidades, as vias de ação abertas no campo perceptivo presumido. Mas o que seria este campo perceptivo presumido? Tudo aquilo que aparece perceptivamente para o sujeito de modo imediato, estando no aqui e agora, mas que atrai a atenção do sujeito em função de suas possibilidades. É aquilo que pode vir a ser, apresentando-se como as "probabilidades" do horizonte de indeterminação, para dizer com Husserl. Poder vir a ser se coloca como presunção na composição desse campo perceptivo que, na atividade esportiva, é um campo competitivo. E o que significa afirmar que essas possibilidades são encarnadas? Isso quer dizer, tão somente, que os pensamentos mais apropriados para a ação corporal esportiva não são reflexivos, mas intuições diretas de suas vias de possibilidade. São, como tais, menos planejamentos e mais simples protensões, são tendências de ação, possibilidades entre as quais, uma comparece à pessoa como a mais propícia ao acerto. Decerto, isso pode não ocorrer, desdobrando-se como vacilo ou a tentativa arbitrária, sem a convicção que, costumeiramente, acompanha as ações esportivas mais qualificadas.

É como espaço público mais bem acabado de testemunho da corporificação mais pura da vontade espontânea numa ação decisiva, que o esporte comparece como fenômeno tão imediatamente apreciável. Da mesma maneira, a reação pessoal àquilo que é sofrido pelo corpo - seja a dor muscular numa corrida de longa distância, ou os impactos e pressões sofridos por oponentes nos esportes de contato - não é proeminentemente o resultado de uma mediação representativa, embora possa ser influenciada por isso. Assim, a resistência, a tolerância e a confiança para o jogo de corpo no exemplo do futebol, ou para a intensidade combativa dos impactos e pressões, no rúgbi, handebol ou esportes de combate, paradigmaticamente, não se conquistam originalmente por alguma virtude de caráter, representação de valores que se procura sustentar na hora da prática. Ainda que sirvam de referência, não são virtudes representativas que vão substituir a constituição de uma norma sensível. É o corpo à prova da experiência, é a experiência à prova de reações e posições pessoais que constituem a persistência. O tensionamento voluntário da própria norma sensível faz a persistência uma virtude esportiva encarnada. Sem esta virtude encarnada não há prática que se desenvolva no ambiente de qualquer disputa corporal regular. Aqui, a persistência co- 
mo virtude esportiva, passa pelo tipo de resistência física que para cada modalidade esportiva e prática corporal será particular, diferenciando-se em razão de suas exigências. Esta pode ser resistência aeróbica, por exemplo. No tensionamento aos limites da resistência vê-se a capacidade afastar-se da vontade: embora se queira mais, a sombra da incapacidade afasta vontade e realização. À insistência em aproximá-los designa-se perseverança, chave volitiva para o alargamento das normas sensíveis pessoais dos esportistas. Trata-se de resistência física, contemporaneamente psicológica e atravessada por influxos volitivos.

As normas sensíveis são provisórias na medida em que variam de lugar a lugar, de tempo a tempo, de sociedade a sociedade, mas também de pessoa a pessoa e, não menos importante, numa mesma pessoa. Nos jogos recreativos, o desconhecimento das normas em certo ambiente e com relação a cada jogador especificamente também deixa um novato alerta com a intensidade das entradas e jogo de corpo. Nas práticas de combate há certa presunção tácita adquirida pela experiência prática de que a intensidade combativa se define por reciprocidade. $\mathrm{O}$ descuido com a intensidade dos golpes pode tornar treinamentos e lutas em situações de descontrole hostil que ascendem como brigas incendiárias (Melo e Barreira, 2015). Assim, praticantes de artes marciais experimentam situações delicadas quando treinam em academias estranhas ou com estranhos, buscando modular normas sensíveis que não são fixas entre diferentes locais de uma mesma prática. Aqui, torna-se literal a admoestação para jogadores e lutadores de que prudência consiste em ter tato nas ações, pois não é como figura de linguagem que o tato participa constitutivamente das normas sensíveis.

Como afirmado, há, além da provisoriedade, precariedade dessas normas. Uma vez que a ação corporal sempre expressa intensidade afetiva, não se pode simplesmente "desligar" o eventual comparecimento de intensificações, desafetos e humores que podem dizer menos respeito ao aqui e agora da prática esportiva do que à permanência hilética - pré-reflexiva, "inconsciente" - da afetividade de acontecimentos prévios e ausentes do agora. Quanto a isso, as possibilidades são muitas e os humores e desafetos "extra-esportivos" - isto é, não exclusivos do recorte temporal da disputa propriamente dita - são influxos que não devem ser subestimados e marcam os desafios interventivos em Psicologia do Esporte. Isso, com efeito, está diretamente relacionado às capacidades e dificuldades de concentração e ativação ideal para a disputa esportiva. Abre-se todo um campo hermenêutico para decifração daquilo que, num dado momento, pode comparecer afetando os limiares pessoais de norma sensível ${ }^{23}$.

\footnotetext{
${ }^{23}$ Basta pensar em tudo o que esteve implícito e aflorou na mais notável intensificação agressiva da história das Copas do Mundo de Futebol. Sem corpo a corpo, fora do lance de alguma jogada, a agressão verbal de Materazzi teve como resposta de Zinedine Zidane, o maior astro do futebol francês, em plena final da Copa de 2006 na Alemanha, a violenta cabeçada que selaria a desvantagem de sua equipe, fatal na derrota para a seleção italiana. Expulso de campo e acusado pela der-
}

Se a precariedade da norma sensível prova a impossibilidade de predição de toda a multiplicidade de forças que podem afetá-la, enfocar este aspecto não ajuda, por outro lado, a compreender os traços constitutivos dessas normas. A interpretação apenas serve para ler uma situação, a posteriori. Decerto, esse conhecimento interpretativo e esse saber prático têm muito maiores alcances. A começar pelos cuidados para que, em psicologia do esporte, as condições ideais com que determinado atleta vai para a disputa não sejam fixadas em parâmetros objetivos exteriores, mas sejam gradualmente identificadas nas próprias experiências esportivas que constituem a história pessoal do atleta em sua modalidade. Também, por exemplo, os esforços para individuar e lidar com esferas afetivas da vida pessoal do esportista, a fim de que uma esfera não se sobreponha inadvertidamente à outra, ocasionando prejuízos ao seu envolvimento e desempenho. Trata-se de uma das razões pelas quais intervenção em psicologia do esporte só deva ser feita por psicólogos. Escavar a constituição das normas de sensibilidade, busca seus elementos a priori. Esses elementos não fazem a norma fixa, mas mostram como ela é, de que é feita, inclusive com atenção à sua faceta oscilante. Assim, excluído tudo aquilo que pode afetá-la e fazê-la caracteristicamente precária, mas que não a constitui essencialmente, chega-se à sua redução.

Provisoriedade e precariedade, portanto, inserem a empatia, sobretudo em sua dimensão primariamente constitutiva, pré-reflexiva, que é a da corporeidade, da hilética, como a percepção decisiva para que os praticantes dos esportes de contato encontrem e modulem suas normas sensíveis $^{24}$. Quando o desafeto se intensifica, arrisca-se a borrar um dos oponentes da disputa que se converte em conflito. Alguém se percebe borrado, vítima da ação agressiva. Há margem para discussão e interpretação quanto à intenção de quem agiu agressivamente. Testemunhas e arbitragem pluralizam a discussão. Alguém protagoniza o borramento do outro, o ataca: essa é posição de quem mais arrisca a consumar indiscutivelmente a violência e o risco de sua escalada.

Boa parte das ocasióes em que o esporte se irrompe em violência não é legível nem por via das frágeis noções do que seja a violência, nem dos conceitos racionalistas de agressão hostil e agressão instrumental. Assim, a análise fenomenológica ilumina essa zona de ambiguidade que, talvez na maioria das vezes, esteja na fonte do processo

rota francesa, após o episódio, Zidane passou por um processo expiatório e redentor, com cerimônias públicas inclusive junto ao Presidente da República em seu país (Poiraud e Teboul, 2007). Pode supor-se que somente uma história de ícone esportivo, junto à compreensão sociológica que remetia a ofensa a um teor colonialista com relação à origem argelina da família do astro, teria tornado o afloramento corporal do ato violento desculpável como o foi para os franceses. Ali, ainda que a violência consumada não fosse defensável, sem se questionar a punição sofrida pelo jogador, ela foi atenuada em virtude de sua motivação, a ofensa à sua dignidade que justificaria sua reação.

${ }^{24}$ Para uma abordagem que destaque essa dimensão primária da empatia no relacionamento mundano e esportivo, veja-se Barreira (2014). 
que leva à distorção destes fenômenos práticos, essencialmente não violentos, que são os esportes, em violência.

\section{Normas de sensibilidade: uma breve sistematização conceitual}

Toda interação humana encontra limites que têm na própria composição corporal sua matéria prima. Pode-se enxergar na corporeidade, isto é, na materialidade viva e sensível em que o ser humano se constitui, a fonte primária e contínua de modos de interação que se configuram com alguma estabilidade e variabilidade. Se isso estiver correto, esse conceito assinala amplamente um embasamento estético da experiência intersubjetiva na esfera hilética, isto é, aquela dimensão da sensibilidade (Husserl 2001, 2011; Ales Bello 2004, 2005, 2006a, 2006b, 2007, 2015; Barreira 2014).

Se a ruptura do fenômeno esportivo na violência foi o ponto de partida para as escavações ora realizadas, não há motivos para restringir suas descobertas àquele território. O aprofundamento da escavação revela uma estrutura vivencial inalienável do ser humano e, como tal, pertinente a seu registro transcendental. Normas de sensibilidade acompanham, em alguma medida, todas as ações corporais, sendo irrestritas, inclusive, aos relacionamentos humanos. Já na interação com animais, a sensibilidade também acha limites que - pelas excitações e reações, pela tonalidade e intensidade, materializada em movimento, vigor, ritmo, tensão - mostram que a elasticidade de toda ação corporal em sua zona de excesso encontra pontos de ruptura que, ao seu modo, delineiam suas fronteiras e, então, índices liminares para suas zonas de normalidade sensível. O que pode ser reconhecido como normal nessas zonas de sensibilidades entre os animais tem condição de ser tipificado em hábitos comunitários que, na interação humana, ganha o estatuto de norma. Esse conhecimento sensível será central para o convívio com animais domésticos ou selvagens, revelando um importante papel à esfera inter-afetiva. Isso também será confirmado nas ações de cuidado, por exemplo, nos gestos com que se busca confortar, alegrar ou acalmar um bebê ou criança que ainda tenha escassos recursos verbais para comunicar o que sente. Não apenas determinados animais domesticados e crianças pedem gestos do tipo e não é apenas a falta de recursos verbais que justifica sua demanda. A demanda por cuidado e conforto corporal acompanha o ser humano ao longo de toda a vida e não só em condições de vulnerabilidade. Diferentes formas de cuidado que contemplam a esfera da corporeidade, atendendo a diferentes demandas, são parte relevante dos exercícios e desenvolvimentos profissionais de áreas como a psicologia e a enfermagem, mas também da pedagogia, da terapia ocupacional, da odontologia, da fisioterapia, da educação física e esporte, apenas para mencionar algumas. Mais do que o tato, normas sensíveis contemplam a inteira esfera dos sentidos corporais como o paladar, o olfato, a audição, a visão, sendo critérios estéticos determinantes em atividades profissionais como a do cozinheiro, do perfumista, do músico e do arquiteto. Na ausência daquilo que a norma sensível contempla, o trabalho clínico em psicologia, por exemplo, perderia referências de trato interpessoal. Incidentalmente, voltada ao campo mais propriamente afetivo, vale mencionar aquilo que se passa em terapias acompanhadas por animais (Borba, 2015), em que o contato com os bichos é capaz de evocar uma sintonização afetiva que, sem ser centrada na interlocução verbal, pode bem ser descrita como modulação empática constitutiva de normas de sensibilidade.

Que o conceito seja amplamente abrangente - mas não por isso necessariamente vago - se mostra pelo fato de que é facilmente identificável nas interações típicas do trânsito de veículos. Sem expressão verbal, não é apenas a obediência às regras, mas os intercâmbios sensíveis que demarcarão a ruptura de limites de tolerância, tão sujeitos aos humores com que motoristas comparecem no tráfe$\mathrm{go}^{25}$. Em outra direção, o corpo a corpo também constitui e modula normas nas carícias e jogos de sedução. Se a existência de regras pode sugeri-las, fica claro, por meio de exemplos como estes, que regra alguma é capaz de prescrever inteiramente as normas de sensibilidade, pois delas participam dinâmica e constitutivamente seus sujeitos. Entretanto, não é demais dizer que os corpos vivos solicitam serem tratados com formas e dosagens que têm seus últimos limites ali onde a sensibilidade corporal é afetada a ponto de ser vivida como desbotamento de seu sujeito. Com isso, deve-se ver no componente sensível também a cultura, que não a constitui como um segundo momento, mas como um entrelaçamento contemporaneamente fundador da norma sensível. Isso não é o mesmo que dar-lhe uma condição relativista. Sua relatividade se interrompe junto ao critério negativo que é o desbotamento do sujeito, ocorrido quando este vivencia um processo coisificador. Ser coisificado avilta-lhe a dignidade, cujo início mais elementar vive no reconhecimento empático

\footnotetext{
${ }^{25}$ A esse respeito é bastante elucidativo que a ausência de norma de sensibilidade modulada pela empatia esteja sendo um problema contemporâneo para os engenheiros que trabalham na construção dos automóveis conduzidos por computadores e sem motorista. Conforme matéria do New York Times intitulada Motoristas reais são o maior desafio para carro autônomo, publicada pela Folha de São Paulo em 4 de setembro de 2015, "um carro do Google, em teste realizado em 2009, não conseguiu atravessar um cruzamento com mão dupla em ambas as direções porque seus sensores ficavam à espera de que os demais motoristas freassem completamente seus carros antes de permitir que ele seguisse. Os motoristas humanos continuavam a avançar aos poucos em busca de uma vantagem - e isso paralisou o robô do Google”. Donald Norman, o diretor de um laboratório que estuda esses carros autônomos, entrevistado na matéria, diz que os carros "precisam aprender a ser agressivos no grau certo, e o grau depende da cultura". Provavelmente, em se tratando de ações previsíveis, mesmo tendo que se adequar a diferenças culturais, a codificação dessas possibilidades no trânsito ainda pode ser capaz de simular e substituir, em grande medida, os padrões de normas de sensibilidade humana - embora não se possa afirmar o mesmo no que tange à empatia.
} 
e se desenvolve em formas de reconhecimento jurídico ${ }^{26}$. Esse limite, embora se diferencie ininterruptamente e se estabilize tipicamente, põe a norma sensível à prova da violência, vendo aí a fronteira que a esfacela. O delineamento dessa fronteira não é casualmente determinado, mas encontrará um preenchimento positivo não apenas em particularidades culturais situadas; obedecerá também a juízos pessoais e particularidades momentâneas próprias ao estado e sentimento vital. Seria demais, contudo, tentar em tão pouco espaço descrever com precisão essa fonte corporal para padronizações sociais de ordem estética. Trata-se aqui apenas de assinalar sua existência e pontuar alguns de seus marcos estruturantes ${ }^{27}$.

Normas de sensibilidade ou normas sensíveis são, antes de qualquer coisa, sentidas e moduláveis, localizando-se materialmente nos corpos próprios dos sujeitos que lhes participam constitutivamente, embora se difundam na atmosfera intersubjetiva, sendo irredutíveis à materialidade corporal. Se são normas, são intersubjetivas, encontrando lugar no mundo social, embora jamais prescindam da esfera individual, sem o que não teriam como se realizar. Assim, as normas de sensibilidade determinam modos de se situar no mundo perceptivo compartilhado, podendo alternativamente ser chamadas de normas intercorporais. Todavia, uma norma sensível pode atuar quando não há outro sujeito presente no aqui e agora - dizendo respeito àquilo que alguém faz com um objeto material, uma vez que o corpo próprio é correlato sensível no contato material com as coisas. Portanto, é mais adequado reservar o uso da expressão alternativa norma intercorporal para aquele momento em que mais de um corpo vivo interage numa modulação normativa. Essa modulação e a norma, enquanto tal, são irredutíveis a razões quantificáveis, sendo qualitativas e qualitativamente variáveis num continum de intensidade. Esse continum presume uma temporalidade que lhes é ontológica, constituindo-lhes e reconstituindo-lhes em suas modulações. Nesta temporalidade se confere que as mesmas têm historicidade: nelas residem referências, heranças, memórias, sedimentações.

As normas de sensibilidade oscilam não apenas objetivamente, isto é, em função de seus padrões sociais; mas subjetivamente, em virtude do sentimento vital próprio

\footnotetext{
${ }^{26}$ Reflexões significativas a esse respeito se encontram em Honneth (2003). Mas é a Husserl e Edith Stein que se deve atribuir a possibilidade de afirmar a importância da empatia como ato perceptivo sui generis em que vive o princípio elementar do reconhecimento.

27 Nem se mencionou, por exemplo, que normas de sensibilidade abrangem também a relação com as coisas e a ação do sujeito direcionada a si mesmo enquanto objeto e corpo próprio - pense-se na intensidade dos exercícios físicos. Esculpir pede modulação dos gestos para que o material resista à intervenção humana; escovar os dentes pede modulação para que o sujeito não se lesione aguda nem cronicamente. Um conhecimento mais explícito de normas de sensibilidade próprias a essas práticas, possivelmente, distingue a capacidade que um artesão tem para ensinar seu ofício ou a que um dentista tem para orientar seus pacientes, para não dizer a que um profissional de educação física tem para ensinar e treinar uma pessoa numa intensidade que não suscite rejeição pela prática.
}

a cada um. Mais uma vez, há de se destacar seu limite: é quando empaticamente um sujeito sente estar sendo desbotado enquanto sujeito que se processa a ruptura violenta da norma. Portanto, normas de sensibilidade se constituem e modulam empaticamente sem se renderem a uma pura convencionalidade, uma vez que é a natureza sensível do corpo próprio que informa para os sujeitos os limites que poderão ser mutuamente reconhecidos. Nos muitos casos em que tais limites não são reconhecidos - ou o são, mas não são respeitados - sua ruptura pode consistir em violência. Sofrendo influxos de diversas forças afetivas, a oscilação individual da norma sensível é virtualmente imprevisível. Sua previsibilidade é qualitativa e se informa com base em si mesma, isto é, na avaliação de sentimentos que tem referências nas normas do gênero. Finalmente, deve-se ver na norma sensível um componente social da face tácita da empatia mundana, o que reitera a abrangência desta dimensão estética da experiência.

Esse texto partiu do interesse em se compreender como, no corpo a corpo da disputa, o fenômeno esportivo perpassa suas fronteiras dilacerando-se ou alcançando o que, supostamente, poderia ser tomado como um tipo de violência socialmente aceitável por estar no território circunscrito e controlado do esporte. Viu-se como essa suposição se embasava numa conceituação débil de violência e, consequentemente, do que seja a ação esportiva. Aqui, a lógica hegemônica que traz conceitos de fora do esporte para interpretá-lo foi invertida. O exame fenomenológico dos liminares esportivos e de sua zona de ambiguidade serviu, efetivamente, como laboratório cujos resultados transcendem o esporte em si. O que se revelou foi que, na consecução de uma violência não programada, mas emergente na interação humana, irrompe-se o limite de uma esfera ineliminável de todas as relações intersubjetivas, a esfera das normas de sensibilidade. Sistematizar conceitualmente as normas de sensibilidade ainda será um desafio investigativo para os estudos em psicologia de perspectiva fenomenológica. Entretanto, ter-se chegado a seu mais provável limite último é, com efeito, a virtude que confirma a experiência esportiva como um laboratório para os estudos psicológicos da pessoa situada no mundo, cujo potencial merece atenção contínua.

\section{Referências bibliográficas}

Ales Bello, A. (2004). Fenomenologia e Ciências Humanas (M. Mahfoud e M. Massimi, Trad.). Bauru: Edusc.

Ales Bello, A. (2005). Phenomenological hyletics and the lifeworld. Analecta Husserliana, LXXXIV, 293-301.

Ales Bello, A. (2006a). Introdução à fenomenologia. (J. Turolo Garcia e M. Mahfoud. Trad.). Bauru: EDUSC.

Ales Bello, A. (2006b). The language of our living body. Analecta Husserliana, LXXXIX, 3-14. 
Ales Bello, A. (2007). Phenomenological hyletics: the animal, the human, the divine. Analecta Husserliana, XCIV, 3-10.

Ales Bello, A. (2015). Pessoa e comunidade: comentários: Psicologia e Ciências do Espírito de Edith Stein. (M. Mahfoud. e J. Turolo Garcia, Trad.). Belo Horizonte: Artesã.

Arendt, H. (1994). Sobre a Violência. (A. Duarte, Trad.). Rio de Janeiro: Relume-Dumará. (Original em inglês publicado em 1969).

Barreira, C. R. A. (2014). A bela adormecida e outras vinhetas: a empatia do corpo a corpo cotidiano à clínica sob a luz da fenomenologia. Em: Savian, J. (2014). Empatia - Edmund Husserl e Edith Stein - Apresentações didáticas. Loyola: São Paulo.

Barreira, C. R. A. (2013). Fenomenologia do combate: da ética da luta à luta pela vida ética. In: Mahfoud, M. \& Massimi, M. (Org.) Edith Stein e a psicologia: teoria e pesquisa. Belo Horizonte: Artesã, p. 413-447.

Barthes, R. (2009). O que é o esporte? (A. Telles, Trad). Serrote, 3, 96-105. (Original em francês de 1961).

Borba, J.M.P. (2015). Saúde na infância, medicalização da existência e as IntervençõesAssistidascomAnimais:alternativa ou "nova" tecnificação? Em : Dantas, J. B. (Org.) A infância medicalizada: discursos, práticas e saberes para o enfrentamento da medicalização da vida. Curitiba: CRV, p. 243-274.

Elias, N. \& Dunning, E. (1994). Sport et civilisation: la violence maîtrise. (J. Chicheportiche e F. Duvigneau, Trad.). Paris: Fayard.

Guilbert, S. (2004). Sport and Violence. International Review for the Sociology of Sport, 39(1), 45-55.

Gumbrecht, H. U. (2007). Elogio da Beleza Atlética (F. Ravagnani, Trad.). São Paulo: Companhia das Letras.

Honneth, A. (2003). Luta por reconhecimento: a gramática moral dos conflitos sociais. (L. Repa, Trad.). São Paulo: 34. (Original em alemão publicado em1992).

Husserl, E. (2001). Sur l'intersubectivité II. Paris: PUF. (Original em alemão publicado em 1973).

Husserl, E. (2006). Idéias para uma fenomenologia pura e para uma filosofia fenomenológica. (M. Suzuki, Trad.). Aparecida: Idéias\&Letras. (Original em alemão publicado em 1911).

Husserl, E. (2007). Filosofia Prima: teoria dela riduzione fenomenológica. (A. Staiti, Trad.). Rubbettino: Soveria Mannelli. (Original em alemão publicado em 1965).

Husserl, E. (2011). Idee per una fenomenologia pura e per una filosofia fenomenologica, Volume II, Libro secondo: Ricerche fenomenologiche sopra la costitutzione, Libro terzo: La fenomenologia e i fondamenti delle scienze. (E. Filippini, Trad.). Torino: Einaudi. (Original em alemão publicado em 1952).

Husserl, E. (2014). Investigações lógicas: prolegômenos à lógica pura: volume 1. (D. Ferrer, Trad.). Rio de Janeiro: Forense. (Original em alemão publicado em 1900).

Mahfoud, M. \& Massimi, M. (2013). Edith Stein e a psicologia: teoria e pesquisa. Belo Horizonte: Artesã.
Melo, F. \& Barreira, C. R. A. (2015). As fronteiras psicológicas entre violência, luta e brincadeira: as transições fenomenológicas na prática da capoeira. Movimento, 21(1), p. 125-138. Recuperado em 10 de setembro, 2015, de file://C:/Users/usuario/Downloads/46298-223025-1-PB\%20(1).pdf.

Poiraud, E. \& Teboul, T. (2007). Amour, gloire et crampons: pour une sociologie du foot. Paris: Les petits matins.

Queval, I. (2009). Le sport. Petite abécédaire philosophique. Paris: Larousse.

Queval, I. (2013). Realizar-se ou se superar: ensaio sobre o esporte contemporâneo. (E. M. L. de Freitas, trad.). Rio de Janeiro: Forense Universitária: Larousse.

Ranieri, L. P. \& Barreira, C. R. A. (2012). A empatia como vivência. Memorandum, 23, 12-31. Recuperado em 28 de abril, 2015, de http://www.fafich.ufmg.br/memorandum/a23/ranieribarreira01.

Sandel, M. J. (2013). Contra a perfeição: Ética na era da engenharia genética. (A. C. Mesquista, trad.). Rio de Janeiro: CivilizaçãoBrasileira.

Savian, J. (2014). Empatia - Edmund Husserl e Edith Stein Apresentações didáticas. Loyola: São Paulo.

Stein, E. (1999). Psicologia e Scienze dello Spirito. (A.M. Pezzela, Trad.). 2. ed. Roma: Città Nuova. (Original em alemão publicado em 1922).

Tenenbaum, G., Stewart, E., Singer, R.N. \&Duda, J.(1997). Aggression and violence in sport: An ISSP position stand. The Sport Psychologist, 11(1), 1-7.

Tyson, M. \& Sloman, L. (2014). Mike Tyson: a verdade nua e crua. (R. C. Francisco et al, Trad.). São Paulo: Saraiva.

Valério, P. H. M. (2014). Capoeira: fluxos originários em rotas marginais. Dissertação de Mestrado, Programa de Pós-Graduação da Escola de Educação Física e Esporte da Universidade de São Paulo, São Paulo, SP.

Weinberg, R. S. \& Gould, D. (2008). Fundamentos da psicologia do esporte e do exercício. (C. Monteiro, Trad.). Porto Alegre: Artmed.

Cristiano Roque Antunes Barreira - É Psicólogo e Doutor pela Faculdade de Filosofia, Ciências e Letras de Ribeirão Preto (USP). Atualmente é Professor Associado (RDIDP) e Diretor da Escola de Educação Física e Esporte de Ribeirão Preto da Universidade de São Paulo - USP. Av. Bandeirantes, 3900 - Monte Alegre. Ribeirão Preto - SP. CEP14040-900. E-mail:crisroba@usp.br

Recebido em 26.07.2016

Primeira Decisão Editorial em 24.01.2017

Aceito em 22.05.2017 